Gut, 1982, 23, 968-973

\title{
Lactose malabsorption in Greek adults: correlation of small bowel transit time with the severity of lactose intolerance*
}

\author{
S LADAS, $\uparrow \mathrm{J}$ PAPANIKOS, and G ARAPAKIS
}

From the Research Unit, Second Propaedeutic Medical Unit of the Athens National University, Evangelismos Hospital, Athens, Greece.

SUMMARY Using breath hydrogen analysis after $139 \mathrm{mmol}(50 \mathrm{~g})$ oral lactose load, we investigated the prevalence of lactose malabsorption in 200 Greek adults and examined the relationship between symptoms and small bowel transit time. One hundred and fifty subjects had increased breath hydrogen concentrations $(>20 \mathrm{ppm})$ after the lactose load. In these individuals peak breath hydrogen concentration was inversely related to small bowel transit time $(r=-0 \cdot 63$, $t=6 \cdot 854, p<0 \cdot 001$ ) and the severity of symptoms decreased with increasing small bowel transit time. Lactose malabsorbers with diarrhoea during the lactose tolerance test had a small bowel transit time of $51 \pm 22$ minutes $(x \pm S D ; n=90)$ which was significantly shorter than the small bowel transit time of patients with colicky pain, flatulence, and abdominal distension $(74 \pm 30, n=53$; $\mathrm{p}<0.001)$ and both groups had significantly shorter small bowel transit time than that of asymptomatic malabsorbers $(115 \pm 21 \mathrm{n}: 7 ; \mathrm{p}<0 \cdot 001)$. When the oral lactose load was reduced to $33 \mathrm{mmol}(12 \mathrm{~g})$, the small bowel transit time increased five-fold and the overall incidence of diarrhoea and/or symptoms decreased dramatically. These results indicate that the prevalence of lactase deficiency in Greece may be as high as $75 \%$ and suggest that symptom production in lactose malabsorbers is brought about by the rapid passage down the small intestine of the malabsorbed lactose.

It is well established that the prevalence of inherited delayed onset lactase deficiency ranges widely (2$100 \%$ ). Most ethnic groups, however, fall into the categories of either low prevalence $(<30 \%)$, or high prevalence $(>60 \%)$. Only mixed ethnic groups fall into the intermediate range $(30-60 \%){ }^{1}$

Recently, Simmons, ${ }^{2}$ in reviewing the topic, concluded that there was inadequate information to categorise the prevalence of lactase deficiency in Greece. This is because there are two major difficulties in interpreting the results of studies to date: first, they included small numbers of Greek adults $(\mathrm{n}: 8-16)^{3}{ }^{4}$ and second the lactose tolerance test with blood glucose determinations was used to

\footnotetext{
* Presented in part at the British Society of Gastroenteroloy, 23-27 Septermber 1981.

+ Address for requests for reprints: Dr S Ladas, Research Unit, Second Propaedeutic Medical Unit, Evangelismos Hospital, Ipsilantou 45. Athens. Greece.

Received for publication 1 February 1982
}

diagnose lactose malabsorption $(\mathrm{n}: 650)^{5}$ which has been shown to give high false negative results. ${ }^{6}$

The breath hydrogen test avoids the recognised problems of blood glucose determinations as an estimation of lactose malabsorption. Moreover, it gives no false positives and negligible negative results and correlates very well with mucosal lactase activity. ${ }^{6}$ It is not invasive and the end-expiratory technique is very simple, quick, and reproducible and therefore convenient for screening large populations..$^{7-9}$ For these reasons, we decided to use the breath hydrogen test to investigate the prevalence of lactose malabsorption in Greek adults.

The breath hydrogen test is, in addition, a well-recognised tool for measuring small bowel transit time ${ }^{1011}$ and the relevance of small bowel transit time to symptoms provoked during the lactose tolerance test has never been investigated in large population studies. Bedine and Bayless ${ }^{12}$ showed that jejunal lactase levels do not correlate 
with the threshold level for symptoms during the lactose tolerance test with increasing doses of lactose. As a result, they assumed that increased speed of transit and intracolonic fermentation also play a role in symptom production. Thus we thought it worthwhile to measure transit time for lactose malabsorbed in our patients and investigate its role with symptoms provoked during the lactose tolerance test, after ingestion of both high (139 $\mathrm{mmol}=50 \mathrm{~g})$ and low $(33 \mathrm{mmol}=12 \mathrm{~g})$ lactose loads.

\section{Methods}

POPULATION STUDY

Two hundred Greek adults were studied, 93 men and 107 women, aged 15 to 80 years (mean 37 years \pm SD 15). Forty-six were born in Northern Greece, 107 in Southern Greece, and 47 in the Greek Islands. Subjects with a major abdominal operation, diabetes mellitus, overt gastrointestinal disease, recent febrile illness or antibiotic treatment were excluded. Verbal informed consent was obtained from all tested individuals.

The first consecutive 100 patients had a lactose tolerance test with both blood glucose and breath hydrogen concentration measurements. Subsequently only breath hydrogen was determined. During the study, 30 lactose malabsorbers had a second lactose tolerance test after ingestion of 33 mmol (12 g) of lactose (equivalent to one glass of milk).

Before the lactose tolerance test information was obtained from each volunteer about their milk drinking habits and awareness of any milk-induced abdominal symptoms.

\section{LACTOSE TOLERANCE TEST}

After an overnight fast $139 \mathrm{mmol}(50 \mathrm{~g})$ of glucosefree lactose was administered to each patient by mouth suspended in $300 \mathrm{ml}$ tap water at room temperature (osmolality: $460 \mathrm{mOsm} / \mathrm{kg}$ ). Capillary blood samples were taken at time zero, 15, 30, 60, 90 , and 120 minutes. A peak rise in blood glucose of less than $1.11 \mathrm{mmol} / \mathrm{l}(20 \mathrm{mg} / \mathrm{dl})$ above the fasting level was considered abnormal (flat). ${ }^{713}$ Breath samples were collected every 15 minutes over three hours. A peak rise in breath hydrogen concentration of more than 20 parts per million (ppm) over the baseline was considered evidence of lactose malabsorption. ${ }^{78}$ Because breath hydrogen concentration has been shown to increase during smoking ${ }^{14}$ smokers were instructed not to smoke.

During the lactose tolerance test (three hours) and for three hours afterwards the occurrence of abdominal symptoms and frequency and consistency of bowel motions were recorded. Lactose intolerance was considered as severe when a patient had diarrhoea and mild when he had colicky pain, increased flatulence, abdominal distension, or borborygmi, but no diarrhoea. Patients who showed no symptoms were defined as asymptomatic malabsorbers.

ASSAYS

Blood glucose was measured by the glucosehexokinase method. End-expiratory breath samples were collected in $50 \mathrm{ml}$ plastic rubber syringes, while the patient exhaled through a modified HaldanePriestley tube, ${ }^{8}$ and then analysed for hydrogen concentrations in a Hewlett-Packard research chromatograph $(5750 \mathrm{G})$ equipped with a thermal conductivity detector. The operating conditions were: injection port and column temperature $50^{\circ} \mathrm{C}$, detector block temperature $100^{\circ} \mathrm{C}$, bridge current 160 milliamps, attenuation 1 and Argon carrier gas of chromatographic purity at flow-rate of $20 \mathrm{ml} / \mathrm{min}$. The copper chromatographic column $(280 \mathrm{~cm}$ long $\times 0.625 \mathrm{~cm}$ diameter) contained molecular sieve $5 \mathrm{~A}, 60 / 80$ mesh. The sensitivity of the method was such that $5 \mathrm{ml}$ (loop volume) injection of a standard mixture $50 \pm 0.8 \mathrm{ppm}$ hydrogen in Argon gave recorder deflection of $50 \mathrm{~mm}$. Hydrogen was very well separated from the other peaks and had a retention time of 3.6 minutes. The total chromatogram was completed in 14 minutes. Hydrogen leakage from the syringes was less than $10 \%$ over 24 hours.

STATISTICAL ANALYSIS

The statistical significance of the results was assessed by either $\chi^{2}$ test or analysis of variance where appropriate.

PREVALENCE OF LACTOSE MALABSORPTION As can be seen from the Table, $75 \%$ of the population tested were found to be lactose malabsorbers according to the breath hydrogen test. The prevalence was the same in the first and second 100 patients studied. Furthermore, there was a strong correlation between lactose malabsorption and intolerance. Thus, $95.5 \%$ of the malabsorbers were symptomatic during the lactose tolerance test. Only $4.5 \%$ of the normal subjects had borborygmi but no other symptoms.

An increase of breath hydrogen concentration of higher then $20 \mathrm{ppm}$ at 120 minutes over the zero time diagnosed 146 of the 150 malabsorbers. The increase in three of the others was delayed until 150 minutes, while in the fourth it was 180 minutes. Significantly, all four patients were symptomatic during the lactose tolerance test and three of them 
Table Prevalence of lactose malabsorption and lactose intolerance (expressed as percentages)

\begin{tabular}{|c|c|c|c|c|c|c|c|}
\hline \multirow[b]{2}{*}{ Group } & \multirow{2}{*}{$\begin{array}{l}\text { Normal } \\
\text { subjects } \\
\text { (no.) }\end{array}$} & \multirow{2}{*}{$\begin{array}{l}\text { Lactose } \\
\text { malabsorbers } \\
\text { (no.) }\end{array}$} & \multicolumn{3}{|c|}{ Lactose malabsorbers $(n=150)$} & \multicolumn{2}{|c|}{ Normal subjects $(n=50)$} \\
\hline & & & Diarrhoea & $\begin{array}{l}\text { Abdominal } \\
\text { symptoms }\end{array}$ & Asymptomatic & Borborygmi & Asymptomatic \\
\hline $\begin{array}{l}\text { I } \\
(n=100) \\
\text { II }\end{array}$ & 26 & 74 & $66 \cdot 0$ & $30 \cdot 0$ & $4 \cdot 0$ & $4 \cdot 0$ & $96 \cdot 0$ \\
\hline $\begin{array}{l}(n=100) \\
\text { Mean }\end{array}$ & 24 & 76 & $57 \cdot 0$ & $38 \cdot 0$ & $5 \cdot 0$ & $5 \cdot 0$ & $95 \cdot 0$ \\
\hline$(n=200)$ & 25 & 75 & $61 \cdot 5$ & $34 \cdot 0$ & $4 \cdot 5$ & $4 \cdot 5$ & $95 \cdot 5$ \\
\hline
\end{tabular}

* Colicky pain, increased flatulence, abdominal distention, but no diarrhoea.

also had a flat blood glucose curve. Thus, using the zero and two hour sample, we detected $97.3 \%$ of the lactose malabsorbers, while the additional use of a 150 minute sample diagnosed $99.3 \%$ of the abnormal population.

The incidence of lactose malabsorption did not differ significantly among the different compartments of Greece (Northern Greece 76\%, Southern Greece $70 \%$, Islands $87 \% \chi^{2}=5 \cdot 198$, $0 \cdot 1>p>0 \cdot 05)$.

\section{BREATH HYDROGEN $v S$ BLOOD GLUCOSE}

ESTIMATIONS

The comparison between the two tests and their correlation with lactose intolerance are shown in Fig. 1. From the first 100 consecutive cases studied $55 \%$ had a flat blood glucose curve. This percentage is significantly less than that obtained by either the

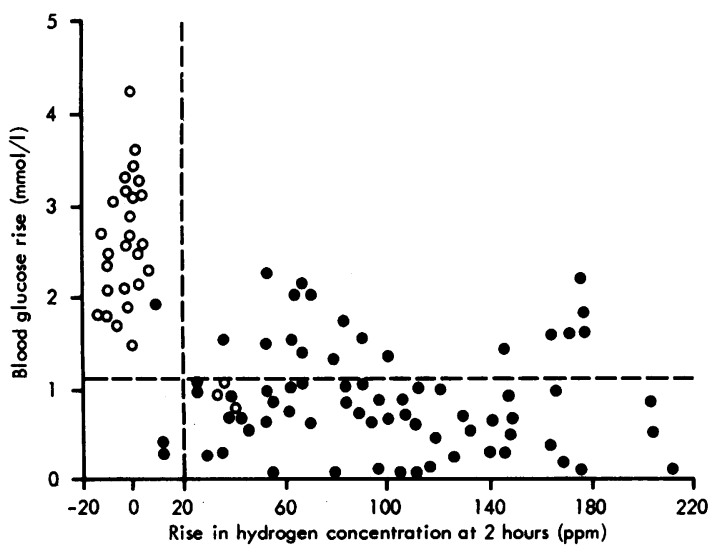

Fig. 1 Maximum rise in blood glucose compared with rise in end-expiratory hydrogen concentration two hours after ingestion of $139 \mathrm{mmol}(50 \mathrm{~g})$ of lactose in $100 \mathrm{Greeks}$. - Abdominal symptoms and/or diarrhoea. $\bigcirc$ No symptoms. $(1 \mathrm{mmol} / \mathrm{l}$ of glucose $=18.02 \mathrm{mg} / \mathrm{dl}$ ) breath hydrogen test $(75 \%)\left(\chi^{2}=7 \cdot 883\right.$, $0.01>p>0.001)$ or the clinical evaluation of the patient's symptoms during the lactose tolerance test $(71.5 \%)\left(\chi^{2}=5.491,0.02>p>0.01\right)$.

\section{CORRELATION OF SMALL BOWEL TRANSIT TIME} WITH BREATH HYDROGEN CONCENTRATION AND LACTOSE INTOLERANCE

In 74 lactose malabsorbers (group I, Table) small bowel transit time was plotted against peak breath hydrogen concentration (Fig. 2). In each individual transit time was calculated as the time taken after lactose ingestion for the expired hydrogen concentration to increase by $20 \mathrm{ppm}$ above the fasting value. There was a negative correlation between the two variables $(r=-0.628, t=6.854$, $\mathrm{p}>0.001$ ).

Furthermore, the correlation of severity of lactose

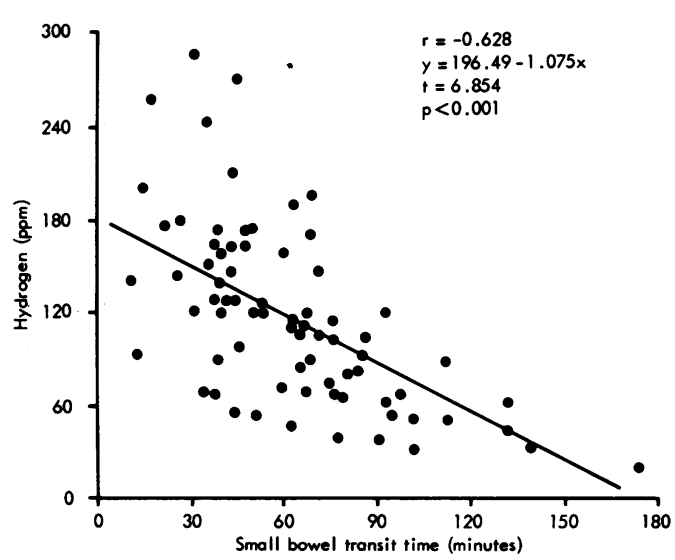

Fig. 2 Correlation of transit time with peak breath hydrogen concentration in 74 lactose malabsorbers (group 1, Table). 
intolerance and small bowel transit time in 150 lactose malabsorbers showed that those patients with severe lactose intolerance, as was judged by the occurrence of diarrhoea during the lactose tolerance test, had significantly shorter mean transit time $(\mathrm{n}=90,51 \pm \mathrm{SD} 22 \mathrm{~min}, \mathrm{p}<0.001)$ than those with mild lactose intolerance (indicated by the occurrence of colicky pain, abdominal distension, increased flatulence, and borborygmi) $(n=53$, $74 \pm$ SD $30 \mathrm{~min}$ ) and any of the groups had significantly shorter mean transit time than that found in asymptomatic malabsorbers $(n=7$, $115 \pm$ SD $21 \mathrm{~min}, \mathrm{p}<0.001)$. The mean breath hydrogen concentration curves of these groups are shown in Fig. 3. Breath hydrogen concentrations at 120 and 150 minutes were significantly different between these three groups $(p<0 \cdot 001)$ and there was a tendency for lower hydrogen concentration in groups with longer transit time.

MODIFIED LACTOSE TOLERANCE TEST ( $33 \mathrm{mmol}$ of lactose oral load)

Only 16 (group I) out of the 30 lactose malabsorbers who had this test demonstrated an increase in breath hydrogen concentration higher than $20 \mathrm{ppm}$ over the zero time (Fig. 4). The mean small bowel transit time for this group increased from 30 to 137 minutes, while the mean peak breath hydrogen concentration decreased from 160 to $37 \mathrm{ppm}$ (ingestion of 139 and $33 \mathrm{mmol}$ of lactose respectively).

In contrast, the remaining 14 patients (group II), failed to give an increase in breath hydrogen concentration higher than $20 \mathrm{ppm}$ over the zero time.

In group I, seven of the 16 individuals tested reported symptoms during the $33 \mathrm{mmol}$ lactose tolerance test. In group II only two of the 14 patients reported borborygmi.

\section{Discussion}

In the present study, the prevalence of lactase deficiency in 200 Greek adults was investigated by means of the breath hydrogen test, after a $139 \mathrm{mmol}$ $(50 \mathrm{~g})$ oral lactose load. Seventy five percent of this population were found to be lactose malabsorbers. The Greek nation thus falls into the group with a high prevalence $(>60 \%)$ of lactase deficiency. ${ }^{1}$

Further analysis of our data has shown that the prevalence of lactase deficiency does not differ significantly between different areas of Greece that is, Northern, Southern Greece, and the Greek Islands. We also found that the malabsorbers consumed milk with the same frequency as normal subjects (milk drinkers $69 \%$ and $62 \%$ respectively), while $34 \%$ of the malabsorbers were aware of their intolerance. Milk drinking habits and awareness of milk intolerance can, however, be affected by factors such as, city or country life, milk availability, and background of the population under investigation. These factors are not related to the prevalence of lactase deficiency and our results should be interpreted with caution, because only a small number of the population was studied.

Our results are in disagreement with those of Kanaghinis et al (lactase deficiency prevalence $75 \%$ vs $45.5 \%, \chi^{2}=51.08, \mathrm{p}<0.001$ ). If we compare our blood glucose test results with those of Kanaghinis et $a l,{ }^{5}$ however, the difference is not statistically significant $\left(55 \%\right.$ vs $\left.45.5 \%, \chi^{2}=2.726, p>0.05\right)$. In our hands blood glucose test gave $19(26 \%)$ false negative results as compared with the breath hydrogen test (Fig. 1), which is in agreement with $24 \%$ reported by Newcomer et al. ${ }^{6}$

Breath hydrogen test, unlike the blood glucose test, gave no false negatives and correlated very well with the lactose intolerance results $(75 \% \%$ vs $\left.71.5 \%, \chi^{2}=0.625, p>0 \cdot 3\right)$. Furthermore, it proved
Fig. 3 Mean ( $\pm S E M)$ breath hydrogen concentration curves vs time in three groups of lactose malabsorbers with severe (group I), mild lactose intolerance (group II), and asymptomatic malabsorption (group III).

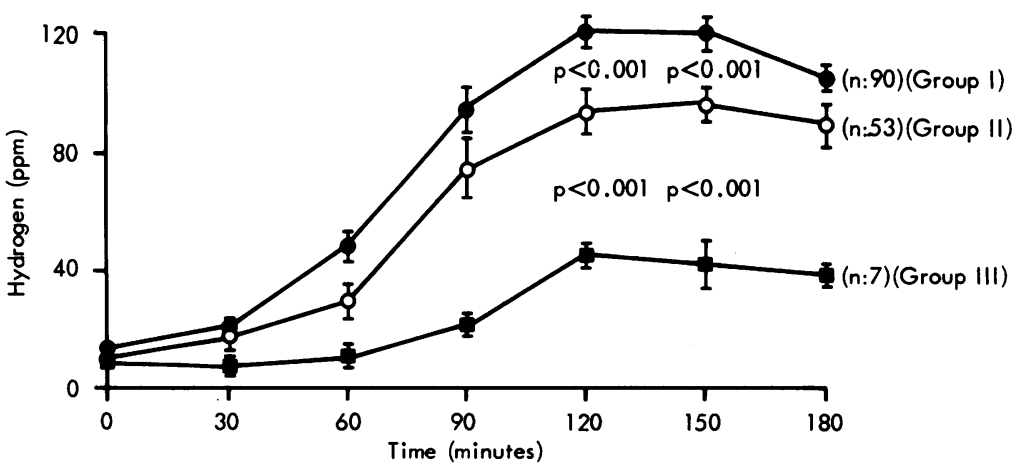


Fig. 4 Breath hydrogen concentration vs time in 30 lactose malabsorbers (groups I and II) after $139 \mathrm{mmol}(50 \mathrm{~g})$ $(\bullet, \mathbf{0})$ and $33 \mathrm{mmol}(12 \mathrm{~g})(\mathrm{O}$, ㅁ) of lactose ingestion.

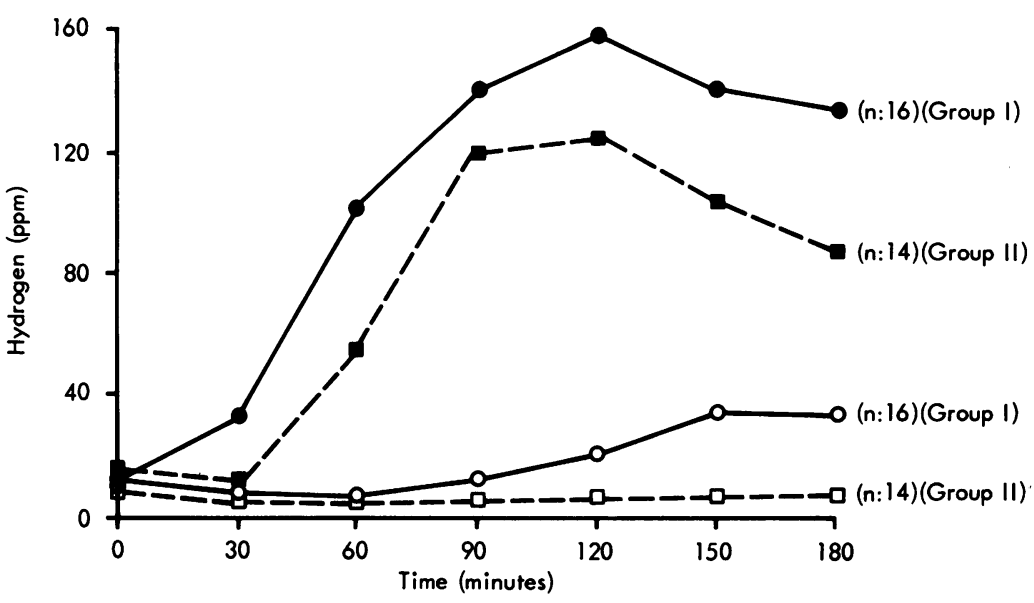

lactose load the incidence of diarrhoea is similarly reduced, presumably because smaller amounts of lactose are malabsorbed. In addition to the size of the lactose load, its rate of delivery to the jejunum may play a role. In this regard it is interesting to note that individuals with normal intestinal lactase activity will malabsorb lactose after gastric surgery. ${ }^{17}$ Furthermore, we have provided evidence that a rapid small bowel transit for lactose is associated with more severe lactose intolerance. ${ }^{12}$ It may be that a rapid small bowel transit will further increase malabsorption by reducing the time during which the lactose is in contact with the intestinal mucosa or that it may also increase the rate of delivery into the colon of malabsorbed lactose, associated with an increased input of fluid and solute. ${ }^{18}$ Finally, the rapidity with which the colonic bacteria ferment lactose may be decisive, as the capacity of the colon to absorb the lactic and short chain fatty acids produced could be exceeded and an osmotic diarrhoea would result. ${ }^{19}$ Clearly intubations and direct measurements of small intestinal and colonic function are necessary to confirm our conclusions from this study using breath hydrogen methods alone.

In conclusion, we have shown that the prevalence of lactase deficiency in Greece is $75 \%$ and about one-third of the population are intolerant to even one glass of milk. The incidence of diarrhoea among lactose malabsorbers is inversely related to small bowel transit time for lactose malabsorbed and there is a tendency for lower breath hydrogen concentrations with increasing transit time. Thus, small bowel transit time of lactose malabsorbed seems to be one of the major determinants of lactose induced symptoms in man. 
We would like to thank Dr G Murphy and Dr D Ruppin for their helpful criticism and advice in the preparation of the manuscript, as well as Mrs S Das for secretarial work.

\section{References}

1 Newcomer AD. Milk, lactase and gene-distribution. Dig Dis 1978; 23: 1232-6.

2 Simmons FJ. The geographic hypothesis and lactose malabsorption: a weighing of the evidence. Dig Dis 1978; 23: 963-80.

3 Neal G. The diagnosis, incidence and significance of disaccharidase deficiency in adults. Proc Roy Soc Med, 1968; 61: 1099-103.

4 Spanidou EP, Petrakis NL. Lactose intolerance in Greeks. Lancet, 1972; 2: 872-3.

5 Kanaghinis T, Hatsioannou J, Deliargyris N, Danos N. Zografos N, Katsas A, Gardikas C. Primary lactase deficiency in Greek adults. Dig Dis 1974; 19: 1021-6.

6 Newcomer AD, McGill DB, Thomas PJ, Hofmann AF. Prospective comparison of indirect methods for detecting lactase deficiency. $N$ Engl J Med 1975; 293: 1232-6.

7 Metz G, Jenkins DJA, Peters TJ, Newman A, Blendis LM. Breath hydrogen as a diagnostic method for hypolactasia. Lancet 1975; 1: 1155-7.

8 Metz G, Gassull MA, Leeds AR, Blendis LM, Jenkins DJA. A simple method of measuring breath hydrogen in carbohydrate malabsorption by end expiratory sampling. Clin Sci Mol Med 1976; 50: 237-40.

9 Metz G, Blendis LM, Jenkins DJA. $\mathrm{H}_{2}$ breath test for lactase deficiency. N Engl J Med 1976; 294: 730.

10 Bond $\mathrm{JH}$, Levitt MD. Investigation of small bowel transit time in man utilising pulmonary hydrogen $\left(\mathrm{H}_{2}\right)$ measurements. J Lab Clin Med 1975; 85: 546-55.

11 Bond JH, Levitt MD. Use of breath hydrogen $\left(\mathrm{H}_{2}\right)$ to quantitate small bowel transit time following partial gastrectomy. J Lab Clin Med 1977; 90: 30-6.

12 Bedine MS, Bayless TM. Intolerance of small amounts of lactose by individuals with low lactase levels. Gastroenterology 1973; 63: 735-43.

13 McGill DB, Newcomer AD. Comparison of venous and capillary blood samples in lactose tolerance testing. Gastroenterology 1967; 53: 371-4.

14 Tadesse K, Eastwood M. Breath hydrogen test and smoking. Lancet 1977; 2: 91.

15 Bond JH, Levitt MD. Use of pulmonary hydrogen $\left(\mathrm{H}_{2}\right)$ measurements to quantitative carbohydrate absorption: study of partially gastrectomized patients. $J$ $J$ Clin Invest 1972: 51: 1219-25.

16 Welsh JD, Payne DV, Manion C. Morrison RD. Nichols MA. Interval sampling of breath hydrogen $\left(\mathrm{H}_{2}\right)$ as an index of lactose malabsorption in lactasedeficient subjects. Dig Dis Sci, 1981; 26: 681-5.

17 Welsh JD, Griffiths WJ. Breath hydrogen test after oral lactose in postgastrectomy patients. Am J Clin Nutr 1980; 33: 2324-7.

18 Bond JH, Levitt MD. Quantitative measurement of lactose absorption. Gastroenterology 1976; 70: 105862.

19 Argenzio AR. Short-chain fatty acids and the colon. Dig Dis Sci 1981; 26: 97-9. 